\title{
IMPACT OF LEADERSHIP ON ORGANISATIONAL EFFECTIVENESS
}

\author{
Dr. S. Ramesha \\ Head External Communications, \\ Vignan, \\ Visakhapatnam
}

\author{
Dr. Haniefuddin Shaik \\ Director CMT, \\ Visakhapatnam
}

\author{
Dr. Shaik Shamshuddin \\ Assistant Professor, \\ GITAM University, \\ Visakhapatnam
}

\begin{abstract}
The implication of this study is related to the impact of Compensation on HRM practices while HR is broadly understood to be an attractive option, its specific impact on performance and value that results not yet been well confirmed by research. HR function's program is similar to all programs and policies, in that learning comes after implementation; therefore, evaluating and reviewing with 360-degree feedback will ensure a more holistic view and systematic evaluation of the success of the outsourcing HR service. The ultimate aim of this study is to unearth the impact of outsourcing on Human resources practices in selected Public sectors of Visakhapatnam like Visakhapatnam Port Trust, Visakhapatnam Steel Plant, Bharat Heavy Plates Limited, Hindustan Ship Yard, Hindustan Petroleum Corporation Limited. Data was collected both from primary and secondary sources. The researcher has personally visited organisations and administered the questionnaire / schedule and collected first hand information through personal interviews. Secondary sources of the data were also used and they include records, reports, files and other published and unpublished materials of the organisations.
\end{abstract}

\section{INTRODUCTION}

One of the four most important factors of production is Human Resource. This Resource has some unique characteristics which separates it from other factors of production. Due to this, human resource is occupies a special place in the business of any organization. Human Resource Management is the function performed in organizations that facilitate the most effective use of people (employees) to achieve organizational and individual goals. HRM involves designing management systems to ensure that human talent is used effectively and efficiently to accomplish organizational goals.

\section{Outsourcing of Human Resources:}

Human Resource outsourcing is considered as an important factor in today's business world. It is constantly growing, especially in the global world where companies outsource not just within their country but across borders. Although there are numerous reasons to outsource, current wisdom dictates that the primary reason a company should look to outsource is to regain and improve focus on strategic business processes. Outsourcing allows a company to focus on broader business strategies while having the less strategic aspects of a business performed by an outside expert.

The organisation must be flexible enough to change, because outsourcing requires a culture shift, including the willingness to work with interdependencies and to take risks. While some costs, such as fixed internal resources, will be reduced or 
avoided, some other costs such as communications and travel will increase. The organisation needs to be able to see these in the context of direct cost savings, and the costs which would have been necessary should outsourcing not have been chosen.

\section{REVIEW OF LITERATURE}

Quinn (1999) emphasized that the affect of outsourcing enables organizations to: (1) concentrate more power than anyone else on the capabilities that customers genuinely care about, (2) innovate constantly to stay ahead of competitors, (3) develop flexibilities to adapt to changing competitor pressures and opportunities, and (4) leverage organizational resources through the capabilities and investments of others. In a survey conducted by Miller (2006), 86 percent of respondents, including top executives, cited that introducing outsourcing into their organisations could increase their overall business outcomes in many areas. Chatterjee, S. R. (2007), opined India is being widely recognised as one of the most exciting emerging economics in the world. Besides becoming a global hub of outsourcing, Indian firms are spreading their wings globally through mergers and acquisitions. Akdemir, 2009). However, in the context of organisational outsourcing, communication can impact on attitudes and behaviours at work. Hence, it appears important for the organisation to communicate the outsourcing issues, including the reason to outsource, and the benefits of outsourcing to employees. light of outsourcing. K. Alef ., et.al., (2013), "The link between perceived human resource management practices, engagement and employee behaviour: a moderated mediation model", researcher contributes to understanding of the mediating and moderating processes through which human resource management (HRM) practices are linked with behavioural outcomes. Researcher developed and tested a moderated mediation model linking perceived HRM practices to organisational citizenship behaviour and turnover intentions. Sarosh Kuruvilla and Aruna Ranganathan (2010) in their research study titled "Globalisation and outsourcing: confronting new human resource challenges in India's business process outsourcing industry" argue that the rapid growth of the outsourcing industry has resulted in both high turnover and labour shortages and at the same time provided employment opportunities to a new group of employees: young upwardly mobile college graduates.

\section{NEED FOR THE STUDY}

In more recent times the need for organisations to compete not just locally but nationally and even globally has led to many organisations recognising the importance of the effective use of the human resource. An approach which has been called human resource management acknowledges the contribution that people management makes to organisational effectiveness and requires the personnel function to be more integrated with the broader objectives of the organisation, adopting a proactive rather than reactive approach. HR practitioners face a tough challenge in anticipating the effect of internal and external changes, the change process occurs in business environments that are themselves changing, resulting in unpredictable outcomes.

\section{OBJECTIVES OF THE STUDY}

- To study and explore the reasons for Human Resource Policies.

- Examine how successful Human Resource Policies and Practices in Automobile Industry.

- Recent developments of HR Practices in selected Automobile industries of Gurgaon .

- To crystallize the impact of HR policies and practices for effective leadership and job performance

\section{A. RESEARCH METHODOLOGY}

The universe for the present study is derived from selected private sector undertakings located in Gurgaon. Since the undertakings chosen from various Automobile Industries, There are different categories of employees in the organization. These different categories are broadly classified into five categories namely workers other wise called as Associates, Lower Management Cadre, Middle Management Cadre, Senior Management Cadre and Top level Management. In the Managerial category there are different cadres, they are Junior Managers, Middle level managers and senior level managers. The researcher has included all the 252 employees here after called as respondents in the sample. The different item relating to both the dependent variables and the intervening variables are provided with alternatives basing on Likert pattern of five point scale. The five response categories together with the numerical values assigned to them for computation are! Strongly agree (2), agree (1), No Opinion (0), disagree (-1), strongly disagree $(-2)$. The tabulations and the results for analysis were done with the help of SPSS (Statistical Package for Social Sciences) version 14, MINITAB version-14 and Microsoft Excel for Statistical measurements such as simple percentages, mean values etc., were used in the present study. Normal test (Z-test) is conducted to know the mean significance difference between the two categories of the respondents. ANOVA test was administered to know the average significant difference 
between the opinion of the respondents belonging to different respondents.

i. Reliability Tests in Study:

Cronbach's alpha can be written as a function of the number of test items and the average intercorrelation among the items. Below, for conceptual purposes, the researcher show the formula for the standardized Cronbach's alpha:

$$
\alpha=\frac{N \cdot \bar{c}}{\bar{v}+(N-1) \cdot \bar{C}}
$$

Here $\mathrm{N}$ is equal to the number of items, c-bar is the average inter-item covariance among the items and vbar equals the average variance. The alpha coefficient for the 78 items is 0.860 , suggesting that the items have highly relatively internal consistency.

\section{ii. Cadre wise Distribution of the Respondents}

\begin{tabular}{|c|c|c|}
\hline CADRE & Frequency & Percent \\
\hline Middle level Managers & 202 & 80.1 \\
\hline Senior level Managers & 50 & 19.9 \\
\hline Total & 252 & 100.0 \\
\hline
\end{tabular}

iii. Department wise Distribution of the Respondents

\begin{tabular}{|c|c|c|}
\hline DEPARTMENT & Frequency & Percent \\
\hline Administration & 66 & 26.3 \\
\hline Marketing and Services & 26 & 10.4 \\
\hline Logistics and Operations & 44 & 17.6 \\
\hline Sales and Distribution & 42 & 16.7 \\
\hline Vendor Management & 25 & 10 \\
\hline Research and Development & 49 & 19.4 \\
\hline Total & 252 & 100.0 \\
\hline
\end{tabular}

iv. Reliability Tests

\begin{tabular}{|c|c|c|c|}
\hline Dimension Name & Alpha & Cases & Items \\
\hline Lower Management & 0.585 & 252 & 11 \\
\hline Middle Management & 0.90 & 252 & 13 \\
\hline Senior Level management & 0.494 & 252 & 6 \\
\hline Top Level management & 0.62 & 252 & 30 \\
\hline Leadership & 0.928 & 252 & 25 \\
\hline Decision Making & 0.708 & 252 & 16 \\
\hline Motivation & 0.875 & 252 & 7 \\
\hline Overall & 0.860 & 252 & 78 \\
\hline
\end{tabular}

\section{B. LIMITATIONS}

Since the important method used in the enquiry is the case study, it has all the limitations associated with it. The generalizations of the study cannot be expected to have universal application. Even when trying to apply to the organization of similar nature, these must be applied with caution. During the collection of information, it was found that officials were rather hesitant and ambivalent in providing the required information and sometimes they were reluctant to discuss. 


\section{DATA ANALYSIS}

i. Overall opinion of the respondents on HR Policies:

\begin{tabular}{|l|c|c|c|c|c|}
\hline \multicolumn{1}{|c|}{ Opinion on HR Policies Style } & $\begin{array}{c}\text { Strongly } \\
\text { Agree }\end{array}$ & Agree & $\begin{array}{c}\text { No } \\
\text { Opinion }\end{array}$ & Disagree & $\begin{array}{c}\text { Stron } \\
\text { gly } \\
\text { disag } \\
\text { ree }\end{array}$ \\
\hline $\begin{array}{l}\text { Well framed HR practices will increase the } \\
\text { organisational effectiveness and performance. }\end{array}$ & 11.1 & 24.6 & & 42.5 & 21.8 \\
\hline Good direction and execution is required & & 23.4 & 6.7 & 69.8 & \\
\hline Levels of Job role and creation is very important & 23.4 & 12.7 & & 63.9 & \\
\hline $\begin{array}{l}\text { Division of proper labour and job description with role } \\
\text { clarity play a significant role in HR Management }\end{array}$ & & 67.1 & & 32.9 & \\
\hline Leaders won't have exemptions & & 5.2 & & 94.8 & \\
\hline $\begin{array}{l}\text { Most people prefer directions rather than taking the } \\
\text { lead and responsibility. }\end{array}$ & 7.5 & 13.1 & 10.3 & 57.9 & 11.1 \\
\hline
\end{tabular}

\section{ii. Overall opinion of the respondents on Initiative Practices of HR:}

\begin{tabular}{|c|c|c|c|c|c|}
\hline Statements On Organization culture & $\begin{array}{l}\text { Strongly } \\
\text { Agree }\end{array}$ & Agree & $\begin{array}{c}\text { No } \\
\text { Opinion }\end{array}$ & $\begin{array}{l}\text { Disag } \\
\text { ree }\end{array}$ & $\begin{array}{l}\text { Strongly } \\
\text { disagree }\end{array}$ \\
\hline Forecasting of the problems is up to the mark? & 26.6 & 54.4 & 17.9 & 1.2 & \\
\hline Quality of the product is up to the mark?? & 25 & 51.2 & 19.8 & 2.4 & 1.6 \\
\hline People do their work efficiently at up to the mark?? & 25 & 52.4 & 20.6 & 1.6 & 0.4 \\
\hline $\begin{array}{l}\text { Morale of employees in the organization is up to the } \\
\text { mark? }\end{array}$ & & 93.3 & 6.7 & & \\
\hline $\begin{array}{l}\text { People take effective measures to meet the anticipated } \\
\text { problems in an Organisation? }\end{array}$ & 25 & 50 & 23 & 1.2 & 0.8 \\
\hline $\begin{array}{l}\text { people in your organization well informed about new } \\
\text { developments? }\end{array}$ & & 43.3 & 53.2 & 2.4 & 1.2 \\
\hline $\begin{array}{l}\text { Organization adapts new changes in Macro } \\
\text { environment? }\end{array}$ & & 69.8 & 28.6 & 1.6 & \\
\hline $\begin{array}{l}\text { Morale of managers in the organization is up to the } \\
\text { mark? }\end{array}$ & & 93.3 & 6.7 & & \\
\hline Impact of HR practices in growth of the organization? & 6 & 94 & & & \\
\hline $\begin{array}{l}\text { How well planned are the work assignments in your } \\
\text { organization? }\end{array}$ & & 87.7 & 11.1 & 1.2 & \\
\hline $\begin{array}{l}\text { How well are your systems and procedures geared to } \\
\text { achieve company goals? }\end{array}$ & & 93.3 & 6.7 & & \\
\hline $\begin{array}{l}\text { How well qualified are people in your organization to } \\
\text { handle the tasks assigned to them? }\end{array}$ & 24.2 & 50.8 & 21 & 2 & 2 \\
\hline $\begin{array}{l}\text { How good are the industrial relations in your } \\
\text { organization? }\end{array}$ & 25 & 75 & & & \\
\hline $\begin{array}{l}\text { Decision making in HR Policies and Practices is up to the } \\
\text { mark? }\end{array}$ & 25.4 & 51.6 & 19.8 & 2 & 1.2 \\
\hline Quality of decisions is up to the mark? & 24.6 & 52 & 20.2 & 2.4 & 0.8 \\
\hline $\begin{array}{l}\text { Degree of effectiveness of decisions on important } \\
\text { issues? }\end{array}$ & 25 & 75 & & & \\
\hline $\begin{array}{l}\text { Degree of acceptance of decisions made by HR in the } \\
\text { organization }\end{array}$ & 24.6 & 53.6 & 18.7 & 3.2 & \\
\hline $\begin{array}{l}\text { Degree of delegation of authority by HR in the } \\
\text { organization }\end{array}$ & & 93.3 & 6.7 & & \\
\hline $\begin{array}{l}\text { Degree to which superior and other managers } \\
\text { interference in others work }\end{array}$ & & 69.8 & 28.6 & 1.6 & \\
\hline
\end{tabular}




\begin{tabular}{|l|c|c|c|c|c|}
\hline Subordinates involvement in making decisions? & & 93.3 & 6.7 & & \\
\hline $\begin{array}{l}\text { Overall decision making involvement in implementing } \\
\text { the HR Policies and Practices? }\end{array}$ & & 69.8 & 28.6 & 1.6 & \\
\hline $\begin{array}{l}\text { Decision-makers are aware of the deficiencies in the } \\
\text { organization }\end{array}$ & 25.4 & 52.4 & 18.3 & 2 & 2 \\
\hline $\begin{array}{l}\text { Success rate of Management in removing the problems } \\
\text { of the organization? }\end{array}$ & & 87.3 & 12.7 & & \\
\hline Top management follow their own policies? & 24.6 & 52.8 & 18.7 & 2.4 & 1.6 \\
\hline $\begin{array}{l}\text { Optimum utilisation of Resources in organization } \\
\text { (money, equipment, people, etc.) it has? }\end{array}$ & & 87.7 & 10.3 & 1.2 & 0.8 \\
\hline Average & 12.25 & 69.87 & 16.18 & 1.20 & 0.50 \\
\hline
\end{tabular}

\begin{tabular}{|c|c|c|c|c|c|}
\hline Your opinion on decision making & $\begin{array}{l}\text { Strongly } \\
\text { Agree }\end{array}$ & Agree & $\begin{array}{c}\text { No } \\
\text { Opinion } \\
\end{array}$ & Disagree & $\begin{array}{l}\text { Strongly } \\
\text { disagree }\end{array}$ \\
\hline $\begin{array}{l}\text { Problem solving with consultation of other employees in } \\
\text { the Organisation. }\end{array}$ & & 75.4 & & 24.6 & \\
\hline $\begin{array}{l}\text { Decisions are generally taken after consultation with top } \\
\text { level management cadre? }\end{array}$ & 62.7 & 24.6 & 12.7 & & \\
\hline $\begin{array}{l}\text { Well aware of all important problems confronted at lower } \\
\text { levels? }\end{array}$ & 2.4 & 72.2 & 24.2 & 0.8 & 0.4 \\
\hline $\begin{array}{l}\text { Technical and professional knowledge is considered in } \\
\text { decision making process? }\end{array}$ & 2 & 72.6 & 24.6 & 0.8 & \\
\hline Decisions made often on analysis with relevant data: & 1.2 & 73 & 0.8 & 24.6 & 0.4 \\
\hline $\begin{array}{l}\text { Adequate information is available for solving the } \\
\text { problems? }\end{array}$ & 62.7 & & 37.3 & & \\
\hline Problems will be solved by groups instead of individuals. & 62.7 & & 12.7 & & 24.6 \\
\hline $\begin{array}{l}\text { The influence an individual ability of problem solving } \\
\text { depends on his skill and competence? }\end{array}$ & & 75.4 & & 24.6 & \\
\hline $\begin{array}{l}\text { Problem solvers are able to anticipate and assess Macro } \\
\text { environmental trends? }\end{array}$ & 17.1 & & 54.8 & 24.6 & 3.6 \\
\hline Mostly Problem solvers depends on precedents? & & 24.6 & & 75.4 & \\
\hline $\begin{array}{l}\text { Problem solvers follow the marks set by Top } \\
\text { management? }\end{array}$ & 24.6 & 75.4 & & & \\
\hline $\begin{array}{l}\text { Ground level reality is aware by Problem solvers in an } \\
\text { organisation? }\end{array}$ & & 71.8 & 24.2 & 2 & 2 \\
\hline $\begin{array}{l}\text { In case of sudden problems the technique PDCA-Plan Do } \\
\text { Check and Act used to be followed? }\end{array}$ & 25.8 & 52.4 & 18.3 & 2 & 1.6 \\
\hline $\begin{array}{l}\text { Lower Management is interested to work with Top } \\
\text { Management in Problem solving? }\end{array}$ & 26.6 & 54.4 & 17.9 & 1.2 & \\
\hline $\begin{array}{l}\text { Earlier decisions will be checked but not considered all } \\
\text { the times? }\end{array}$ & & 75.4 & 24.6 & & \\
\hline $\begin{array}{l}\text { After solving the Problems arised will be circulated for } \\
\text { inferences and feedback issues? }\end{array}$ & 24.6 & & & 75.4 & \\
\hline Average & 19.52 & 46.69 & 15.75 & 16 & 2.04 \\
\hline
\end{tabular}


iv. Overall opinion of the respondents on Communication of HR Practices:

\begin{tabular}{|c|c|c|c|c|c|}
\hline opinion on Organizational effectiveness & $\begin{array}{c}\text { Strongly } \\
\text { Agree }\end{array}$ & Agree & $\begin{array}{c}\text { No } \\
\text { Opinion }\end{array}$ & Disagree & $\begin{array}{c}\text { Strongly } \\
\text { disagree }\end{array}$ \\
\hline $\begin{array}{c}\text { All the employees in the Organisation will be communicated } \\
\text { new challenges and issues related to HR Practices? }\end{array}$ & & 75.4 & 24.6 & \\
\hline $\begin{array}{c}\text { Only after clear communication only Poilicies will be adopted } \\
\text { and accepted by employees? }\end{array}$ & 62.7 & 12.7 & 24.6 & & \\
\hline $\begin{array}{c}\text { Review and control of Practices will be done by senior } \\
\text { management cadre at all levels? }\end{array}$ & 19 & 61.9 & 14.7 & 3.6 & \\
\hline $\begin{array}{c}\text { In daily job practices it is considered effectively that practices } \\
\text { should not effect the smooth flow of working environment? }\end{array}$ & & 75.4 & 24.6 & & \\
\hline $\begin{array}{c}\text { All the people will share information when it is required and } \\
\text { asked by others? }\end{array}$ & 11.1 & 75.4 & 6.7 & 6.7 & \\
\hline $\begin{array}{c}\text { Problems will be solved with clear discussions by effective } \\
\text { communication of participation? }\end{array}$ & & 75.4 & & 24.6 & \\
\hline Adequate Management Information system is there? & & 75.4 & 24.6 & & 0.11 \\
\hline Average & 13.26 & 64.52 & 13.6 & 8.50 & \\
\hline
\end{tabular}

v. Significant difference in the average opinion scores of respondents belongs to different Management Cadres:

\begin{tabular}{|c|c|c|c|c|c|c|c|}
\hline Dimension & $\begin{array}{l}\text { INCOME } \\
\text { (In Rupees) }\end{array}$ & $\mathrm{N}$ & Mean & S.D & F-value & P-value & Decision \\
\hline \multirow{4}{*}{$\begin{array}{l}\text { Leadership } \\
\text { Style }\end{array}$} & Low level Managers & 61 & 0.1656 & 0.2089 & \multirow[t]{4}{*}{0.43} & \multirow[t]{4}{*}{0.734} & \multirow[t]{4}{*}{ N.S } \\
\hline & $\begin{array}{l}\text { Middle Level } \\
\text { Managers }\end{array}$ & 111 & 0.1955 & 0.1800 & & & \\
\hline & Senior Level Managers & 44 & 0.1720 & 0.1971 & & & \\
\hline & Top Level Managers & 36 & 0.1704 & 0.1640 & & & \\
\hline \multirow{4}{*}{$\begin{array}{l}\text { Organization } \\
\text { culture }\end{array}$} & Low level Managers & 61 & 0.8236 & 0.3950 & \multirow[t]{4}{*}{2.69} & \multirow[t]{4}{*}{0.047} & \multirow[t]{4}{*}{$\mathrm{S}$} \\
\hline & $\begin{array}{l}\text { Middle Level } \\
\text { Managers }\end{array}$ & 111 & 0.9777 & 0.3277 & & & \\
\hline & Senior Level Managers & 44 & 0.8964 & 0.3433 & & & \\
\hline & Top Level Managers & 36 & 0.9489 & 0.3456 & & & \\
\hline \multirow{4}{*}{$\begin{array}{l}\text { Decision } \\
\text { making }\end{array}$} & Low level Managers & 61 & 0.5754 & 0.4203 & \multirow[t]{4}{*}{1.44} & \multirow[t]{4}{*}{0.232} & \multirow[t]{4}{*}{ N.S } \\
\hline & $\begin{array}{l}\text { Middle Level } \\
\text { Managers }\end{array}$ & 111 & 0.6857 & 0.3695 & & & \\
\hline & Senior Level Managers & 44 & 0.6584 & 0.3723 & & & \\
\hline & Top Level Managers & 36 & 0.7178 & 0.3614 & & & \\
\hline \multirow{4}{*}{$\begin{array}{l}\text { Organization } \\
\text { effectiveness }\end{array}$} & Low level Managers & 61 & 0.6662 & 0.6120 & \multirow[t]{4}{*}{1.33} & \multirow[t]{4}{*}{0.266} & \multirow[t]{4}{*}{ N.S } \\
\hline & $\begin{array}{l}\text { Middle Level } \\
\text { Managers }\end{array}$ & 111 & 0.8347 & 0.5489 & & & \\
\hline & Senior Level Managers & 44 & 0.7750 & 0.6255 & & & \\
\hline & Top Level Managers & 36 & 0.8606 & 0.5681 & & & \\
\hline
\end{tabular}


ISSN (Online): 2455-366

EPRA International Journal of Multidisciplinary Research (IJMR) - Peer Reviewed Journal Volume: 6 | Issue: 7 | July 2020 || Journal DOI: 10.36713/epra2013 || SJIF Impact Factor: 7.032 ||ISI Value: 1.188

vi. Significant difference in the average opinion scores of respondents belongs to different departments on all the dimensions:

\begin{tabular}{|c|c|c|c|c|c|c|c|}
\hline Dimension & EXPERIENCE & $\mathbf{n}$ & Mean & S.D & F-value & P-value & $\begin{array}{l}\text { Decis } \\
\text { ion }\end{array}$ \\
\hline \multirow[t]{5}{*}{ Leadership style } & Administration & 96 & 0.1958 & 0.1925 & \multirow[t]{5}{*}{1.52} & \multirow[t]{5}{*}{0.196} & \multirow[t]{5}{*}{ N.S } \\
\hline & $\begin{array}{l}\text { Marketing and } \\
\text { Services }\end{array}$ & 32 & 0.1542 & 0.2021 & & & \\
\hline & $\begin{array}{l}\text { Logistics and } \\
\text { Operations }\end{array}$ & 49 & 0.1306 & 0.1947 & & & \\
\hline & Sales and Distribution & 33 & 0.2101 & 0.1761 & & & \\
\hline & Vendor Management & 42 & 0.2008 & 0.1583 & & & \\
\hline \multirow{5}{*}{$\begin{array}{l}\text { Organization } \\
\text { culture }\end{array}$} & Administration & 96 & 0.9546 & 0.3303 & \multirow[t]{5}{*}{1.97} & \multirow[t]{5}{*}{0.10} & \multirow[t]{5}{*}{ N.S } \\
\hline & $\begin{array}{l}\text { Marketing and } \\
\text { Services }\end{array}$ & 32 & 0.9225 & 0.3322 & & & \\
\hline & $\begin{array}{l}\text { Logistics and } \\
\text { Operations }\end{array}$ & 49 & 0.8 & 0.4236 & & & \\
\hline & Sales and Distribution & 33 & 0.9830 & 0.33174 & & & \\
\hline & Vendor Management & 42 & 0.9419 & 0.3320 & & & \\
\hline \multirow[t]{5}{*}{ Decision Making } & Administration & 96 & 0.6604 & 0.3671 & \multirow[t]{5}{*}{1.49} & \multirow[t]{5}{*}{0.206} & \multirow[t]{5}{*}{ N.S } \\
\hline & $\begin{array}{l}\text { Marketing and } \\
\text { Services }\end{array}$ & 32 & 0.6619 & 0.3842 & & & \\
\hline & $\begin{array}{l}\text { Logistics and } \\
\text { Operations }\end{array}$ & 49 & 0.5884 & 0.4443 & & & \\
\hline & Sales and Distribution & 33 & 0.6106 & 0.3739 & & & \\
\hline & Vendor Management & 42 & 0.7729 & 0.3347 & & & \\
\hline \multirow{5}{*}{$\begin{array}{l}\text { Organization } \\
\text { effectiveness }\end{array}$} & Administration & 96 & 0.7765 & 0.6308 & \multirow[t]{5}{*}{0.80} & \multirow[t]{5}{*}{0.529} & \multirow[t]{5}{*}{ N.S } \\
\hline & $\begin{array}{l}\text { Marketing and } \\
\text { Services }\end{array}$ & 32 & 0.8206 & 0.5346 & & & \\
\hline & $\begin{array}{l}\text { Logistics and } \\
\text { Operations }\end{array}$ & 49 & 0.6837 & 0.5875 & & & \\
\hline & Sales and Distribution & 33 & 0.8 & 0.5480 & & & \\
\hline & Vendor Management & 42 & 0.8969 & 0.5218 & & & \\
\hline
\end{tabular}

vii. Significant difference in the average opinion scores of respondents belongs to different experiences of employees on all the dimensions:

\begin{tabular}{|c|c|c|c|c|c|c|c|}
\hline Dimension & AGE & $\mathbf{n}$ & Mean & S.D & F-value & P-value & Decision \\
\hline \multirow{2}{*}{ Leadership Style } & Less than 5 Years & 22 & 0.1394 & 0.2193 & \multirow[t]{2}{*}{1.01} & \multirow{2}{*}{0.390} & \multirow[t]{2}{*}{ N.S } \\
\hline & Less than 25 years & 59 & 0.1842 & 0.2023 & & & \\
\hline \multirow{3}{*}{$\begin{array}{l}\text { Organization } \\
\text { culture }\end{array}$} & Less than 5 Years & 22 & 0.8491 & 0.4049 & \multirow[t]{3}{*}{0.93} & \multirow[t]{3}{*}{0.427} & \multirow[t]{3}{*}{ N.S } \\
\hline & Less than 15 Years & 67 & 0.8848 & 0.3425 & & & \\
\hline & Less than 25 years & 59 & 0.9668 & 0.3403 & & & \\
\hline \multirow{3}{*}{ Decision making } & Less than 15 Years & 67 & 0.6393 & 0.3963 & \multirow{3}{*}{0.62} & \multirow{3}{*}{0.602} & \multirow{3}{*}{ N.S } \\
\hline & Less than 25 years & 59 & 0.7046 & 0.3653 & & & \\
\hline & Above 25 years & 104 & 0.6613 & 0.3860 & & & \\
\hline \multirow{2}{*}{$\begin{array}{l}\text { Organization } \\
\text { effectiveness }\end{array}$} & Less than 5 Years & 22 & 0.7855 & 0.6214 & \multirow[t]{2}{*}{0.27} & \multirow[t]{2}{*}{0.848} & \multirow[t]{2}{*}{ N.S } \\
\hline & Less than 15 Years & 67 & 0.7433 & 0.6287 & & & \\
\hline
\end{tabular}




\section{MAJOR FINDINGS}

- Pearson correlation of HR Policies and Practices $=0.371, \mathrm{P}-$ Value $=0.000$, there is a significant relationship between the two dimensions Decision making and Leadership style

- Pearson correlation of Problem solving and Organization culture $=0.395$, P-Value $=$ $0.000, \mathrm{P}$-value divulges that the relationship between the dimensions leadership style and organization culture is significant at 0.05 level.

- Pearson correlation of communication and Organizational effectiveness $=0.375, \mathrm{P}$-Value $=0.000$, the correlation coefficient $\mathrm{r}$-value and $\mathrm{P}$-value indicates that there is a significant correlation between leadership style and organizational effectiveness at $5 \%$ level of significance.

- Pearson correlation of various departmental effectiveness $=-0.229$, P-Value $=0.000$, there is a significant correlation between autocratic leadership style and organizational effectiveness. Also the r-value suggests that there is a negative correlation between both the dimensions.

- It is indicated that Democratic Leadership Style is very much important factor which is contributing for the effectiveness of the organization.

- There is a significant correlation between autocratic leadership style and organizational effectiveness. Also the r-value suggests that there is a negative correlation between both the dimensions.

- It indicates the difference in between these age groups may be that the company is giving preference to the experience personnel at managerial levels.

- $\quad$ people are responsible for themselves and one else, thus the leader con not be blamed for or take credit for the work of his subordinates.

- There is no significant difference for the dimensions of leadership style, decision making and organizational effectiveness. However there is a significant difference in the opinion of the respondents from the four categories in terms of organization culture.

- With regard to experience wise responses on all dimensions there is no significant mean difference in opinion score between the experience groups with respect to the said dimensions, whereas the score on organization culture is more when compared with the remaining dimensions.

- Autocratic style of leadership the results are negative which indicated that both the cadres are not in favour of autocratic style of leadership and it is not at all contributing for the effectiveness of the organization.

E. Suggestions:

- Most of the respondents opined that periodical performance reviews are not being conducted in a regular manner, hence it is suggested that the concerned management of the organization can take necessary steps in order to conduct performance reviews regularly.

- It is suggested that the management should take necessary steps to make the culture of the organization much better.

- It is also suggested that frequent training programs for managers shall be conducted to equip themselves with latest techniques in order to withstand themselves during the tough competition in the present globalize scenario.

- It is suggested that the management should take necessary steps to advise such managers to be Democratic.

\section{F. CONCLUSION}

The business management environment has become severe in recent years and that organizational development strategies often need transforming. Thus, a business is more eager than ever for those who have the transformational leadership being able to change organizational strategy and culture and being able to enable the organization to be more adaptable to external environmental requirements. It is certain that a business also expect these that have the charismatic leadership and the visionary leadership of being self-confident and competent for expressing visions. Furthermore, subordinates will be inspired with more potential by such leadership styles and make more mental and physical efforts for organizations. Therefore, an organization can start from adjusting the leadership style if wanting to promote the organizational performance. Leadership is a dynamic and flowing process involving the interplay of the situations, the followers, and the goals with the behaviour of the leader 


\section{REFERENCES}

1. Jago, A. G. (1982). "Leadership: perspectives in theory and research." Management Science; Providence. March, pp.315-337.

2. Manz, C. C., \& Sims, H. P., Jr. (2001). The new Super Leadership: Leading others to lead themselves. San Francisco: Berrett-Koehler.

3. Glenn R. Smith, Brian H. Kleiner, (1987) "Differences in Corporate Cultures and their Relationship to Organisational Effectiveness", Leadership \& Organization Development Journal, Vol. 8 Iss: 5 , pp. $10-12$

4. David L. Turnipseed, (1988) "An Integrated, Interactive Model of Organisational Climate, Culture And Effectiveness", Leadership \& Organization Development Journal, Vol. 9 Iss: 5, pp. $17-21$

5. Fisher and Edward (1988) "Consideration and initiating structure and their Relationship with leadership effectiveness: A meta analysis", best study Proceedings, Academy of Management Journal. 24-25.

6. Chelladurai, P. (1987). "Multidimensionality and multiple perspectives of organizational effectiveness". Journal of Sport Management, 1(1), 37-47.

7. Ayma, Roya; Kreicker, "Issues in the Assesment of managerial and Leadership" Noel A.; Masztal, Jaci Jarrett (1994) Consulting Psychology Journal: Practice and Research, Vol 46(1), 64-77.

8. French, John R.P Jr. and Bertram Raven(1959), "The bases of Social power", in studies of social power, ed, Dorwin Cartwright, Ann Arbor: university of Michigan Press, 150-167.

9. Cameron, K.S., Whetton, D.A., 1981, Perceptions of organizational effectiveness over organizational life cycles, Administrative Science Quarterly, 26(4) 525-44.

10. Goodman, P.S and Pennings, J.M. New perspectives in organizational effectiveness. San Fransico, Jossey-Bass, 36-41.

11. Price, J.L. (1972).The Study of Organisational Effectiveness, Sociological Quarterly, 13(3) 3-15.

12. Molnar, J.H., Rogers, D.C., 1976, Organisational effectiveness: an empirical comparison of the goal and system resource approaches, Sociological Quarterly, 17 401-13.

13. Elenkov DS (2002). Effects of leadership on organizational performance in Russian companies. J. Bus. Res., 55(6): 467-480.

14. Campbell JP (1977). On the natural of organizational effectiveness, In Goodman PS , Pennings JM (Eds.), New Perspectives on Organizational Effectiveness, Jossey-Bass, San Francisco, CA., 2:13-55

15. Howell JM, Frost PJ (1989). A laboratory study of charismatic leadership. Organizational Behavior and Human Decision Processes, 43(2): 243-269.
16. Warriner, C.K., 1965, The problem of organizational purpose, Sociological Quarterly, Spring, 139- 65.

17. Bardach, E., 1977, The implementation game: what happens after a Bill becomes law, Cambridge, Mass, MIT Press.

18. Kahn, R.L., 1977, Organisational effectiveness: an overview, Goodman, P.S. \& Pennings, J.M. New Perspectives on Organisational Effectiveness. San Francisco, Jossey-Bass, 235-48.

19. Warner, K.W., 1967, Problems in measuring goals of voluntary associations, Journal of Adult Education, 19 3-14. Cameron, K.S., 1981c, Domains of organizational effectiveness in colleges and universities, Academy of Management Journal, 24(1) 25-47. 